\title{
SAME OBJECTIVES, DIFFERENT GOVERNANCE - HOW THE EXCELLENCE INITIATIVE AND THE PACT FOR RESEARCH AND INNOVATION AFFECT THE GERMAN SCIENCE SYSTEM
}

TORGER MÖLLER

\section{INTRODUCTION}

$\mathrm{R}$ esearch funding can be characterized as an instrument used by funding councils and science policy makers to affect the research of individual researchers, organizations or the whole research system. Research topics and funding schemes should be carefully chosen to achieve the funders' goals. More than ten years ago the German federal government and the states had the overall objective to strengthen the German science and university system and their international competitiveness by focusing mainly on research excellence. They initiated two large research funding programs: the Excellence Initiative (ExV) and the Pact for Research and Innovation (PFI). The two funding programs have both similarities and differences. While the Excellence Initiative is dedicated to the university system, the Pact for Research and Innovation focuses on the public non-university research organizations. Although the Excellence Initiative and the Pact for Research and Innovation pursue the same goal, different funding and governance mechanisms are applied. This leads to two questions: What are the reasons for choosing different forms of funding in order to fulfill objectives that are to a great extent identical? How do these differing governance mechanisms affect the universities and the public non-university science system? The effects will be observed by bibliometric and research and development (R\&D) indicators.

\section{FUNDING SCHEMES AND GOVERNANCE MECHANISMS}

The governance perspective has increased continuously over the last decade and has influenced the research on higher education and science studies. For instance, the model of the "Governance Equalizer" (Boer, Enders, \& Schimank, 2007; Schimank, 2005) differentiates analytically between five dimensions of governance: state regulation, stakeholder guidance, academic self-governance, managerial self-governance and competition. In an international comparison the German higher education system could traditionally be characterized by both a relatively strong state regulation and a relatively strong academic selfgovernance, but an undergoing profound process in the last years has transformed the universities more and more into organizational actors (Krücken, 2011).

What is the underlying funding and governance mechanism of the Excellence Initiative and the Pact for Research and Innovation? The governance of the Excellence Initiative is based on competition. The science policy aim of the program was to promote a "performance spiral" (ExV), which should lead to a higher performance und a better international standing of the German universities. Proposals for competitive grants have to be submitted and are reviewed in a group peer review process. The highly selective funding scheme (Möller, Antony, Hinze, \& Hornbostel, 2012) produces temporarily funded winner universities. In contrast, the central science policy aim of the Pact for Research and Innovation was to give the public research organizations financial planning security, which means that the block grant steadily rises for the public non-university research organizations by an annual rate of 3\% (2006-2010 and 2016-2020) respectively 5\% (2011-2015)

It begs the question why the federal government and the states decided to run different funding schemes (competitive versus block grants) in the two programs which have largely the same goals, to strengthen the German science and university system and their international competitiveness. ${ }^{1}$ Two developments framed the conceptualization phase of the Excellence Initiative: An ongoing debate since the 90s about the "rotten" German universities (Glotz, 1996, p. 1; Simon, 1991, p. 52) and the results of the international university rankings (Shanghai 2003, THE 2004), which show that the German universities could not keep up with the top 50 worldwide leading universities. During this time the managerial self-governance of universities was highly questionable. It seemed that the competitive governance mechanism had to be the modus op-

In addition, the Excellence Initiative and the Pact for Research and Innovation support collaborations between the universities and the non- university research organizations as well as promoting young researchers and gender equality. The Pact for Research and Innovation gives a somewhat greater weight on the cooperation with the industry. 
erandi for giving new impulses to the German university system - according to the ideas of New Public Management. In contrast, it looked as though the federal government and the states had a deeper trust in the managerial self-governance of the non-university research organizations, which also had a higher research performance than the universities (see below). The governance mechanism of the Pact for Research and Innovation can be described as external state guidance in the format of a target agreement, in which the science policy sets the main objectives, but gives the non-university research organizations the freedom to choose the appropriate activity for achieving the given goals (GWK, 2014). Every year the non-university research organizations have to report their annual activity. The future amounts are independent of the degree of target achievement.

\section{METHODOLOGY}

The paper is based on data of the German Federal Statistical Office (Statistisches Bundesamt) and bibliometric data of the Web of Science (WoS). The development of the research and development expenditures and the third-party funding were analyzed. In addition, data from the monitoring report of the Pact for Research and Innovation (GWK, 2014, pp. 77-79) is included, because the Federal Statistical Office did not report annually the third-party funds of the non-university research organizations. For the bibliometric analysis the publications of the humanities and social sciences were excluded, due to a very low coverage in the WoS. For the analysis of the proportion of publications that belong to the worldwide top 10\% highly cited papers (PP Top 10\%, Bornmann, 2014; Waltman \& Schreiber, 2013) only citable document types (articles, reviews) were considered and measurement field and doctype normalized in a three year citation window. All calculations have been processed on the database of the German Competence Center for Bibliometrics.

The study covers the time period from 2005 to 2012. The year 2005 was the last year before the financial support from both the Excellence Initiative and the Pact for Research and Innovation has started. The investigation period ends 2012 because the first funding period of the Excellence Initiative terminated in this year.

In order to differentiate the effects of the two funding programs, different units were analyzed separately: $0 n$ the one hand the universities and on the other hand the non-university research organizations Helmholtz Association (HGF), Max Planck Society (MPG), Leibniz Association (WGL) and Fraunhofer Society (FHG). In addition three university subgroups were separated by their success in the Excellence Initiative. First, the nine so called Universities of Excellence (UoE), which are successful in each of the three funding lines (the graduate schools, the cluster of excellence and the university future concept), second, the 37 universities with success in at least one funding line (ExIn Uni) and third, the universities without any funding in the Excellence Initiative (No ExIn Uni). For the bibliometric approach only eight Universities of Excellence (UoE) were considered, because a separate analysis was not applicable after the merger between the University of Karlsruhe and the Helmholtz Center Karlsruhe. The address normalization was made in the German Competence Center for Bibliometrics (Schwechheimer, Rimmert, \& Winterhager, 2015).

\section{RESULTS}

\subsection{RESEARCH AND DEVELOPMENT EXPENDITURES AND THIRD-PARTY FUNDING}

How do different governance mechanisms affect the universities and the non-university research organizations? Figure 1 shows the development of the R\&D expenditure and Figure 2 the third-party funding of the universities (without the university hospitals) and non-university research organizations (NURO). The data were normalized to the year 2005.

Figure 1 shows similarities and differences between the university and the non-university sector. During the time period from 2005 to 2012 the growth of R\&D expenditure are almost the same for the university and the non-university sector (Uni 150\%; NURO 148\%). While the funding by the Pact for Research and Innovation fully comes to bear in 2006, the financial support of the Excellence Initiative rises slowly over the first two years. Some initial projects started in November 2006 and the last approved projects began their work at the end of 2007. So 2008 is the first year in which all the projects of the Excellence Initiative were running.
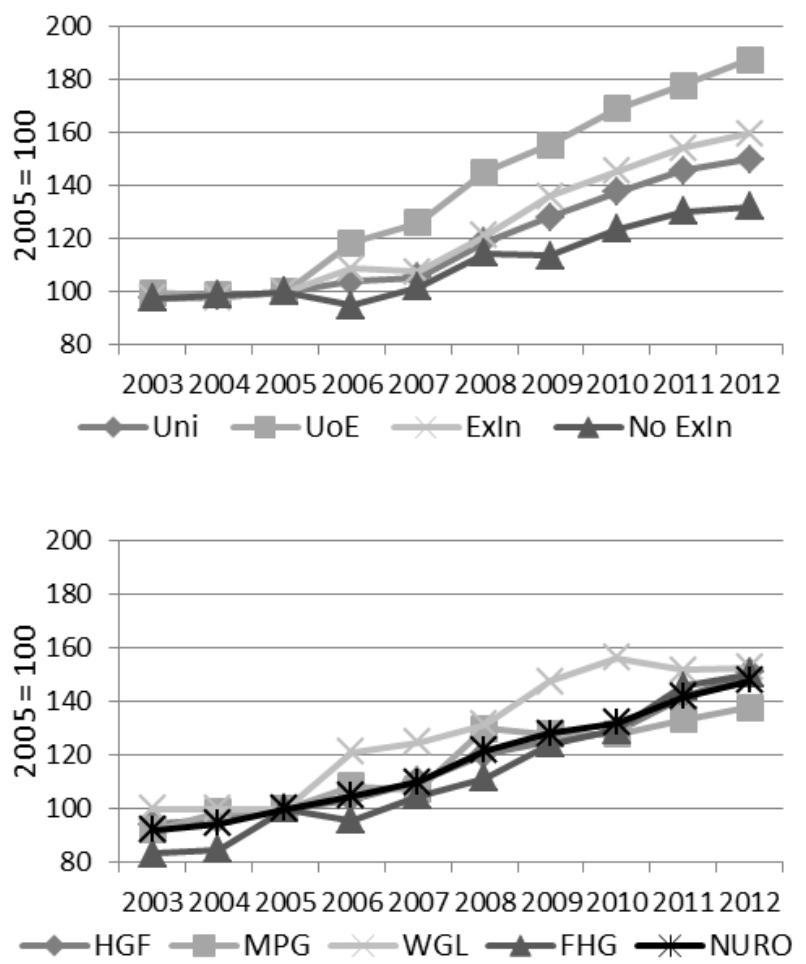

Figure 1: Development of the R\&D expenditures of the university groups (w/o hospitals) and the non-university research organizations (NURO)

The increase of the universities of excellence (UoE 187\%) and the excellence universities (ExIn 160\%) are above the average while the nonexcellence universities have a lower growth rate (No ExIn 132\%). These results indicate an ongoing stratification process in the German university system. In comparison, the R\&D expenditures of the non-university research organizations show a similar increase: WGL 153\%, HGF 151\% and the FHG $150 \%$. Only the MPG has a slightly lower growth rate (138\%). 

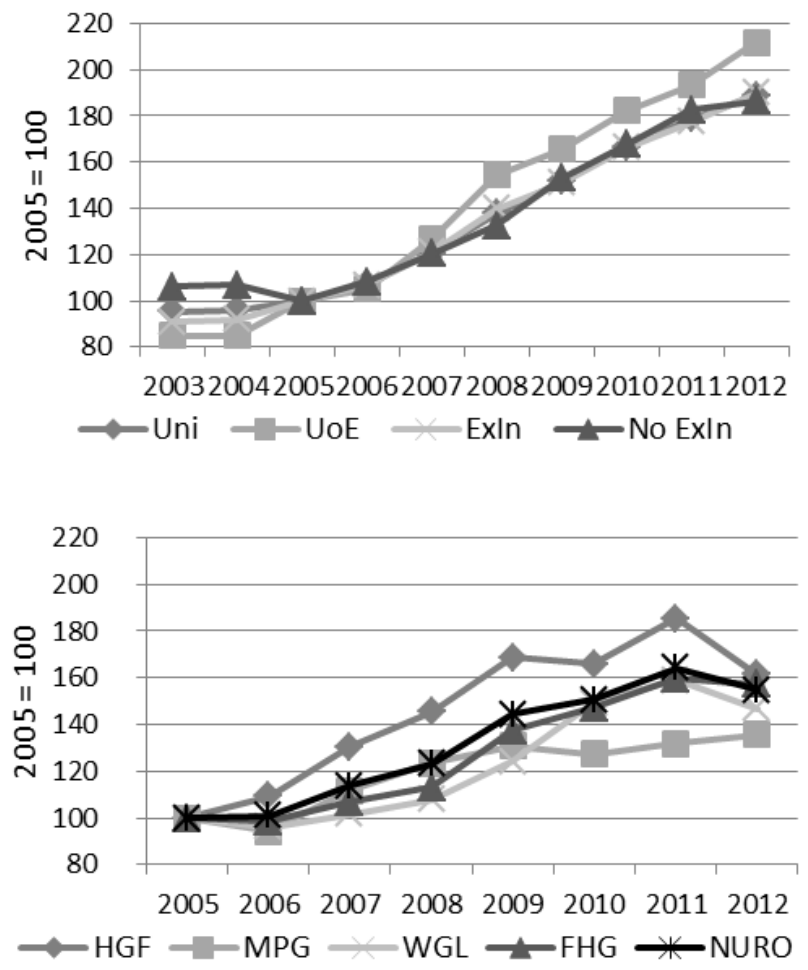

Figure 2: Development of the third-party funding of the university groups (w/o hospitals) and the non-university research organizations (NURO)

The third-party funding (Figure 2) of the university groups rises more sharply than the non-university research organizations (Uni 189\%; NURO $155 \%)$. The UoE (212\%) have the highest growth rate within the university sector, but the overall stratification in the university sector is not as distinctive as in terms of the R\&D expenditures (Figure 1). The universities with and without an excellence funding have an almost similar increase (ExIn 190\%, No ExIn 186\%). The third-party funding for nonuniversity research organization - except the MPG - decreased sharply in 2012, because a federal funding program supporting research infrastructures in the non-university research sector during the financial crisis (2009-2011) was terminated. The HGF has the highest growth of third party funding (161\%) followed by the FHG $(157 \%)$, the WGL $(147 \%)$ and the MPG (136\%).

\subsection{BIBLIOMETRICS}

For the bibliometric analysis (Figure 3) the indicator proportion of publications that belong to the top $10 \%$ worldwide highly cited papers (PP Top 10\%) is applied. The university groups show the above mentioned differentiation: The UoE (year 2012: 17.2\%) is exceeding the ExIn universities (15.1\%) followed by No ExIn Universities (13.5\%). Above the overall German average (14.5\%) are the UoE, and the ExIn universities.

The annual results for the FHG differ over time by a low number of publications, but it should be noted that publication or citation indicators are not very appropriate for an organization, which has a strong applied research and industry collaboration mission. The best performers in 2012 measured by the PP Top $10 \%$ indicator are the MPG (22.6\%) and the HGF $(19.9 \%)$ followed by the WGL (14,8\%). The non-university research organizations have overall higher impact (NURO 19.0\%) than the university sector $(14.4 \%)$.
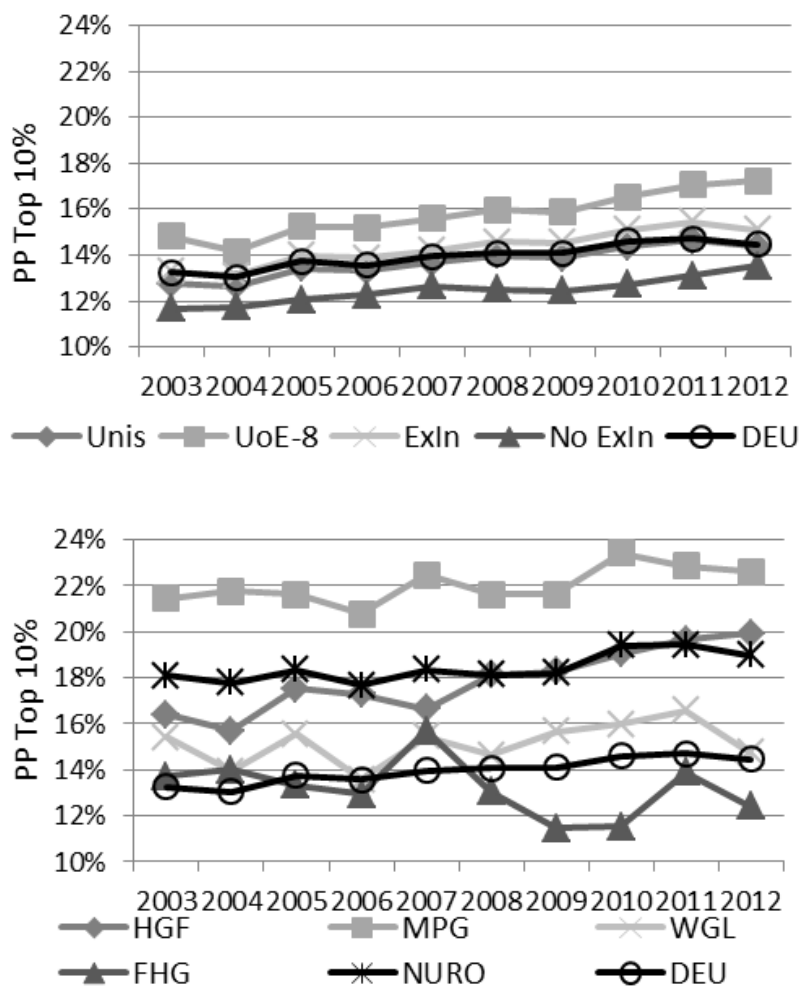

Figure 3: Proportion of publications that belong to the top $10 \%$ worldwide highly cited papers (PP Top 10\%) of the university groups (w/o hospitals) and the non-university research organizations (NURO)

\section{DISCUSSION}

The Excellence Initiative and other third party funding programs have changed the research conditions of the universities. The third-party funding rises more sharply than the total R\&D expenditures (Figure 1 \& 2). As shown in Table 1 in 2005 39\% of the R\&D expenditures of the university sector were based on third party funding. In 2012 it increased to $49 \%$. The results indicate where to a different governance of funding leads: The competitive funding enhances the share of third party funding, while a growth in basic funding has the converse effect. For the non-university sector with a steady increase in basic funding, the share of third party funding stays almost at the same level (2005: 31\%; 2012: 33\%).

\begin{tabular}{|l|l|l|l|l|l|l|l|l|l|}
\hline & Uni & UoE & ExIn & No ExIn & NUR0 & HGF & WGL & MPG & FHG \\
\hline 2005 & $39 \%$ & $51 \%$ & $44 \%$ & $31 \%$ & $31 \%$ & $23 \%$ & $23 \%$ & $17 \%$ & $64 \%$ \\
\hline 2012 & $49 \%$ & $58 \%$ & $52 \%$ & $44 \%$ & $33 \%$ & $25 \%$ & $26 \%$ & $16 \%$ & $70 \%$ \\
\hline
\end{tabular}

Table 1: Share of third party funding of the total R\&D expenditures of the university groups (w/o hospitals) and the non-university research organizations (NURO)

The university groups have a higher share of third party funding than the non-university research organizations, except the FHG. In comparison with the bibliometric results it can be concluded that a high share of third-party funding does not necessarily correlate with a higher value of PP Top $10 \%$ indicator. The MPG with the lowest share of third party funding (2012: 16\%) is the outperformer of the German research system 
in terms of the PP Top 10\% indicator. For a valid comparison between the universities and the non-university research sector further aspects should be taken into account, e.g. discipline related financial demands, the industry mission orientated research (e.g. of the FHG), or large research infrastructure (e.g. German Electron Synchrotron [DESY] as a part of HGF). All these factors are limiting the direct comparison between universities and non-university research organizations.

Within the university groups the UoE have the highest share of third party funding (2012: 58\%) followed by the ExIn (52\%) and the No ExIn (44\%) universities. Considering that the third party funding does not cover the whole research expenditures, the success in attracting additional funds may yield, especially for the most competitive and successful universities, into internal governance problems. A report of the German Research Foundation (DFG) stated that depending on differences between the research fields and topics, from $30 \%$ up to $300 \%$ of the personal costs of a research project have had to be co-financed from the universities (DFG, 2013). This is over, in part far over the given flat rate of $20 \%$ overhead budgets provided by the German Research Council.

Former findings based on guided interviews with university leaders and researchers in the Excellence Initiative show, that - with a growing amount of co-financing - the universities are more and more restricted in their future scope of actions (Bukow \& Möller, 2013). The ability to act, however, is essential for the organizational self-governance of a university. As some studies pointed out, organizational autonomy is an important factor for success in attracting competitive funds (Aghion, Dewatripont, Hoxby, Mas-Colell, \& Sapir, 2010; Boer, Jongbloed, Enders, \& File, 2010). Extensive competitive funding that limits the self-governance of the universities through a high degree of not fully funded research costs, can have in the end no or the opposite effects. In contrast to the universities, the non-university research organizations have a greater ability to choose the appropriate activity also within the funding scheme Pact for Research and Innovation.

Currently, we are facing a new trend in some German states (e.g. Baden-Württemberg, Thüringen). They have reduced their competitive and program based funding in favor of an annual increase in basic funding. Similarly to the Pact for Research and Innovation, the state BadenWürttemberg assures an annual increase of $3 \%$ until 2020. The explicit aim of the science policy makers is to give the universities more flexibility and autonomy and less state regulation (Baden-Württemberg, 2015, p. 6). After a period focusing mainly on the competitive governance mechanism, science policy makers seems to rethink their toolbox instruments and emphasis also other factors that are relevant for the university selfgovernance, their autonomy and productivity.

\section{REFERENCES}

Aghion, P., Dewatripont, M., Hoxby, C., Mas-Colell, A., \& Sapir, A. (2010). The governance and performance of universities: evidence from Europe and the US. Economic Policy, 25(61), 7-59. https://doi. org/10.1111/j.1468-0327.2009.00238.x

Baden-Württemberg (2015). Perspektiven 2020. Hochschulfinanzierungsvertrag Baden-Württemberg 2015-2020. Retrieved from https:// mwk.baden-wuerttemberg.de/fileadmin/redaktion/m-mwk/intern/dateien/publikationen/411503_MWK_Infografiken_Broschuere_RZ_onl.pdf

Boer, H. de, Enders, J., \& Schimank, U. (2007). On the Way towards New Public Management? The Governance of University Systems in England, the Netherlands, Autria, and Germany. In D. Jansen (Ed.), New Forms of Governance in Research Organizations, 137-152. Dordrecht: Springer.

Boer, H. de, Jongbloed, B., Enders, J., \& File, J. (2010). Progress in higher education reform across Europe, Funding reform, Volume 1: Executive Summary and main report. Enschede: Centre for Higher Education Policy Studies (CHEPS). Retrieved from http://doc.utwente.nl/88692/

Bornmann, L. (2014). How are excellent (highly cited) papers defined in bibliometrics? A quantitative analysis of the literature. Research Evaluation, 23(2), 166-173.

Bukow, S., \& Möller, T. (2013). Die Rekrutierung wissenschaftlichen Spitzenpersonals in der Exzellenzinitiative. Berlin: Institut für Forschungsevaluation und Qualitätssicherung (IF0).

DFG (2013). Bericht der Deutschen Forschungsgemeinschaft über die Erfahrungen mit der Gewährung der Programmpauschale in der zweiten Programmphase. Retrieved from http://www.gwk-bonn.de/fileadmin/ Papers/DFG-Bericht-2013.pdf

ExV, Exzellenzvereinbarung (2005): Bund-Länder-Vereinbarung gemäß Artikel 91 b des Grundgesetzes (Forschungsförderung) über die Exzellenzinitiative des Bundes und der Länder zur Förderung von Wissenschaft und Forschung an deutschen Hochschulen. 18.07.2005. BAnz S. 13347.

GWK (2014). Pakt für Forschung und Innovation Monitoring-Bericht 2014. Bonn: Gemeinsame Wissenschaftskonferenz (GWK).

Glotz, P. (1996). Im Kern verrottet?: fünf vor zwölf an Deutschlands Universitäten. Stuttgart: Deutsche Verlags-Anstalt.

Krücken, G. (2011). A european perspective on new modes of university governance and actorhood. Research \& Occasional Paper Series, 17(11), $1-11$.

Möller, T., Antony, P., Hinze, S., \& Hornbostel, S. (2012). Exzellenz begutachtet: Befragung der Gutachter in der Exzellenzinitiative. Berlin: Institut für Forschungsevaluation und Qualitätssicherung (IFO). 
PFI, Pakt für Forschung und Innovation (2005). Retrieved from: http:// www.gwk-bonn.de/fileadmin/Papers/pakt_fuer_forschung_und_innovation.pdf

Schimank, U. (2005). A Comparative Perspective on Changes in University Governance in Europe. Public Lecture at The Australian National University on 17.0ctober 2005

Schwechheimer, H., Rimmert, C., \& Winterhager, M. (2015). Dokumentation zur Institutionenkodierung. Version 1.4. Bielefeld: Kompetenzzentrum Bibliometrie.

Simon, D. (1991). Die Universität ist verrottet. Der Spiegel, 1991(50/1991), 52-53.

Waltman, L., \& Schreiber, M. (2013). On the calculation of percentilebased bibliometric indicators. Journal of the American Society for Information Science and Technology, 64(2), 372-379.

\section{AUTHOR}

\section{TORGER MÖLLER}

German Centre for Higher Education Research and Science Studies (DZHW)

Schützenstr. 6a, 10117 Berlin, Germany

E-mail: $\underline{\text { moeller@dzhw.eu }}$

\section{ACKNOWLEDGEMENT}

This study was funded by the German Expert Commission for Research and Innovation and the German Federal Ministry of Education and Research. All calculations have been processed on the database of the German Competence Center for Bibliometrics. 